\title{
The Appearance of the Military as A Political Force in Indonesia
}

\author{
Abdul Rahman* \\ Fakultas Ilmu Sosial \\ Universitas Negeri Makassar \\ Makassar, Indonesia \\ abdul.rahman8304@unm.ac.id
}

\author{
Firdaus W. Suhaeb \\ Departemen of Sociology \\ Faculty of Social Science \\ Universitas Negeri Makassar \\ Makassar, Indonesia \\ firdaus.w.suhaeb@unm.ac.id
}

\author{
Nurlela \\ Fakultas Ilmu Sosial \\ Universitas Negeri Makassar \\ Makassar, Indonesia \\ nurlela@unm.ac.id
}

\author{
Alfin Dwi Rahmawan \\ Fakultas Ilmu Sosial Dan Ilmu Politik \\ Universitas Bangka Belitung \\ Bangka, Indonesia \\ alfindwirahmawan98@gmail.com
}

\begin{abstract}
This study aims to determine the background of the emergence of the military as a political force in Indonesia. The method used is the historical method by performing four stages, namely: heuristics, criticism, interpretation, and historiography. The results showed that the occurrence of regional upheaval that wanted to separate from the Unitary State of the Republic of Indonesia during the Old Order era, as a form of disappointment with the central government, was considered by the military as a threat to the integrity and sovereignty of the nation and state. Therefore, the military considers the need for a political concept and strategy to overcome this. So the concept of an army middle ground was initiated by Abdul Haris Nasution which in turn gave birth to Dwifungsi. As the embodiment of Dwifungsi, the military seeks to ward off threats that come from within and outside. With the enactment of a state of danger or martial law law, the military will increasingly carry out its political functions by keeping in view the state situation at that time.
\end{abstract}

\section{Keywords: Military, political force, dwifungsi}

\section{INTRODUCTION}

The Indonesian army never limited itself to being a military force. During the revolutionary period from 1945 to 1949 , the army was involved in the struggle for independence where political and military actions were inseparably linked [1]. Immediately after the transfer of power at the end of 1945 , the army officially accepted the principle of superiority of civilian government. The officers assumed that their role in the political sphere could be necessary at any time, but in fact they never emerged as a political force as a result of the parliamentary system of government which was becoming increasingly apparent [2]. Although the army leadership was not directly responsible for the breakdown of the parliamentary system in 1957 , they were able to take advantage of the situation to declare martial law, which eventually allowed army officers to have a greater role in political, administrative and economic functions [3].

In July 1958, the military was recognized as a functional political force. And representatives of military representatives were successfully seated in the state institutions of the National Council which were formed by the government based on the SOB or the martial law. Even though the National Council which was formed by the government was said to be institutional, it was a central state body which played a big role in the political decision-making process at that time. It was also at that time that the role of the political parties that had begun to grapple with the political crisis since the founding of the Republic of Indonesia. Since that time, the participation of the military in politics and government has become increasingly stable, especially after the military in a short time succeeded in overcoming the national crisis of the rebellion of the Revolutionary Government of the Republic of Indonesia.

In order to obtain a justification for the continued role of the army in these functions after the crisis has passed, the Chief of Staff of the Army, Abdul Haris Nasution formulated a concept called the middle way which stipulates that the army will not seek an opportunity to take over the government, but also will not. be indifferent to politics. In addition, the military also demanded their right to remain in government, representative institutions and administration. In the first seminar held in April 1965, the army initiated a doctrine which states that the armed forces have a dual role, namely as a military force and a socio-political force (Muhaimin, 2002: 2). The military activities in question cover the fields of ideology, politics, socio-economy, culture and religion.

In order to obtain a justification for the continued role of the army in these functions after the crisis has passed, the Chief of Staff of the Army, Abdul Haris Nasution formulated a concept called the middle way which stipulates that the army will not seek opportunities to take over the government, 
but also will not. be indifferent to politics. In addition, the army also demands their right to remain in government, representative institutions and administration. In the first seminar held in April 1965, the army initiated a doctrine which states that the armed forces have a dual role, namely as a military force and a socio-political force (Muhaimin, 2002: 2 ). The military activities in question cover the fields of ideology, politics, socio-economy, culture and religion.

\section{METHODOLOGY}

The process of writing this article uses the historical research method which consists of four stages. The stages are (1) Heuristic, which is looking for historical traces in the form of a series of events contained in written notes in the form of books, newspapers and online daily. (2) Criticism, namely providing an assessment of these historical traces by making comparisons with each other to find historical facts that are closer to objective. (3) Interpretation, provides an interpretation of historical traces that have been objectively assessed and then connects them with other historical traces so that historical stories that are related to one another (causality) are compiled. (4) Historiography, the activity of compiling historical stories through written reports in the form of articles for display to the public. Types of research

\section{RESULT AND DISCUSSION}

\section{A. A Brief History of Military Birth}

In the Republic which was just proclaimed on 17 August 1945, there was no regular national army. The new Republic of Indonesia will slowly but surely need officers in order to defend and defend the country's independence and sovereignty. From these things it can be seen that a new country that was born in a hot situation and an environment full of threats from outside, does not have an army of nationalities. This causes most of the youth and armed fighters to have a strong opinion, it is a delay and a big mistake if the proclamation of independence is not immediately followed by a statement or decree by the state leadership and a revolution to make Heiho and PETA's exsoldiers as the National Army. the state army which is the very important apparatus in determining the upright collapse or sinking of a country [4]. The first organization to be formed was the People's Security Agency (BKR) on August 22, 1945 with the aim of maintaining security together with the people and state agencies concerned. The BKR will be placed under the direction of the KNIP, and its branches will be established at all lower levels of government, under the supervision of the regional branches of the Indonesian National Committee (KNI).

BKR has succeeded in gathering former PETA, Heiho, and other laskar soldiers, and the BKR is a maximum defense institution that can be formed if it has the circumstances and conditions at that time, however the existence of BKR [5] does not give satisfaction to youths and fighters who emphasize on the spirit of leadership and the strength of arms, especially in the youth kalnhan which later developed in the Indonesian national army organization. Abdul Haris Nasution in expressing his opinion about the problems at that time, which was a reflection of the situation at that time that: "the main mistakes at the beginning of the revolution were a source of various difficulties for the state in the following years, and especially became the state's difficulties, either in terms of ensuring domestic security as well as in terms of carrying out the perfect defensive " [6].

The landing of allied forces at the end of September forced the government to seriously consider the question of whether it would oppose the Dutch invasion by military means, or by continuing the low-pitched policy of fighting for national independence through negotiations with the Dutch and by ask allies for good in the process. In fact, the Dutch government in The Hague showed no tendency to voluntarily relinquish its former colonies, and the laskar were determined to allow Dutch soldiers to set foot on Indonesian soil [7]. Thus, whatever policy the Indonesian government will adopt, it must strengthen its armed forces so that it can stay in control of a dangerous situation. Thus, on 5 October 1945, the BKR was changed to the People's Security Army (TKR) [8]. As the name implies, TKR's main function is still to maintain domestic security and not face enemies from outside. However, at least his status had been upgraded to become an army.

The existence of an army organization called TKR, which is in a modest condition and is formed in a political and state situation, is not satisfactory, especially for those who have received training and training (for example in KNIL and PETA). TKR is still considered to represent the government's doubts which emphasize its struggle in the field of diplomacy. In addition, TKR is still populist or still prioritizes domestic security [9]. According to the opinion of those who focused on Indonesia's struggle in the field of weapons and violence, what was more important was needed at that time, a tool and national defense organization to face allies, especially against the Dutch who were trying to colonize Indonesia again [10].

With the continued arrival of British troops including Dutch troops, the Republic of Indonesia took a more symbolically militant stance. On January 1, 1946, the Ministry of Security was renamed the ministry of defense, a clear sign that the ministry of defense at that time assumed responsibility from the wider State. At the same time the People's Security Army was transformed into the People's Salvation Army [11]. However, this name was still unsatisfactory and on January 24, TKR was given a new name as Tentara Republik Indonesia (TRI).

The state's situation made its existence even more dangerous, due to the actions of the Dutch which increasingly threatened the life of the Republic of Indonesia in the military and diplomacy fields [12]. In the face of moments like these, the Republic of Indonesia itself did not take action in one direction or in tune. The Soekarno-Hatta-Syahrir government on the one hand, with the army and lasykar on the other, had a different strategy in dealing with the Dutch, namely the government used a diplomatic strategy, while the majority of the military and almost all lasykar used a physical strategy [13].

To overcome these difficulties and problems in the military sector, on May 5, 1947, President Soekarno issued an edict to form a committee led by the President himself. This State Committee was later named Indonesian National 
Army Organization Formation Committee with a membership of 21 people from the leaders of the armed forces, including the leaders of some of the most influential lasykar [14]. After how long working with all the difficulties, on June 7, 1947, a Presidential decree was issued to form an army organization called the Indonesian National Army, abbreviated as TNI, as a form of TNI perfection. In this stipulation, it was decided that at that time the TNI would function as a means of state defense [15].

\section{B. Army and Politics}

The era of guided democracy is the starting point for the expanding role of the military in the Indonesian political system. If during Parliamentary democracy there was subjective civilian control of the military, in the era of guided democracy, the military responded by exercising subjective control over political parties. In order to do this, the military still needed to divide its roles with President Soekarno[16]. Even so, in this era the military has not really been able to cripple all political parties because President Soekarno still provided protection for the Indonesian Communist Party (PKI) [17], which President Soekarno PKI later used as a balancing force against the military, especially the TNIArmy. Slowly but surely the military was able to take power away from the hands of civilian politicians and then paralyze the power of political parties.

Soekarno and Abdul Haris Nasution were of the opinion that Indonesia needed an ideology to be accepted, at least by consensus by all levels of Indonesian society. Politically, it stands to reason that the Constituent Assembly was dissolved because it was seen as an arena for politicians to engage in ideological conflicts [18]. One of the intentions of Nasution in the National Council to reuse the 1945 Constitution was to create an ideological pattern for the entire nation, including especially the TNI itself. In shaping the ideology for guided democracy, the TNI played no role at all, but President Soekarno himself was the initiator. The main ideological formulation put forward by Soekarno was the content of his state speech on August 17, 1949 entitled "Rediscovery of Our Revolution", which was considered a Political Manivesto or MANIPOL [19].

The contents of the Manipol were refined and refined by Soekarno and Roeslan Abdul Gani as chairman of the Supreme Advisory Council formed by President Soekarno under the 1945 Constitution, which was basically a direct incarnation of the National Council with changes in several of its members, and then made Manipol the National political base in under leading democracy. The contents of the Manipol are then summarized into five principles, namely: the 1945 Constitution, Indonesian Socialism, Guided Democracy, Guided Economy and Indonesian Personality which is abbreviated as USDEK. The Usdek Manipol is linked to the foundation of the state so that Pancasila and Manipol Usdek become a series of guided democratic ideology patterns that quickly dominate all communication media in an effort to carry out campaigns and propaganda to the Indonesian people in order to maintain stability and domestic security.

The period between 1956 and 1958, marked by attempted coup d'etat in West Java, blatant defiance against the central government in areas outside Java, and strife within the broader army constituted the greatest leadership crisis the TNI has experienced to date, resulting in causing conflict within the military. The fact that the Headquarters group has been able to survive and even strengthen its position is thanks to Abdul Haris Nasution's political acumen, so that he can slowly reduce the conflict. The military under Nasution was gradually becoming more assertive in playing a role in politics. Since the end of 1956, Army Headquarters began to sound its voice on political issues, and with the enactment of war conditions throughout the archipelago in March 1957 he held great power in almost all fields (Muhaimin, 2002: 17).

The role that the Army could try to seize depended primarily on the strength of the other centers of power. As far as the regionals were concerned, they would soon be destroyed. Masjumi and PSI were so closely associated with the rebellion that their influence quickly declined. But it is not only the strengths of other centers of power that must be taken into account, but also the weaknesses of the army itself. It is true that the army has gained great prestige in certain circles thanks to its successful campaign against the rebels in the regions, but on the other hand it has lost the support of the party, including Masjumi and PSI

Meanwhile, the parties that supported the army against the rebels were also deeply disappointed by the tough attitude in carrying out their duties as war rulers. Thus towards the end of 1958, the army became very unpopular and from a political point of view found itself isolated and had only relations with the Juanda cabinet and mutual interests with President Soekarno [4]. This situation did not become an obstacle for the Army Headquarters to continue to try to play a broader political role. This can be partly explained in terms of urgent military considerations. With the existence of a modern military force, the national defense strategy is still based on the concept of guerrilla warfare [20].

The operations which have been carried out against the various rebels have reinforced the belief that military campaigns alone, without political and economic policies, will not provide a lasting solution. Therefore, the right of the military to participate in determining policies in the nonmilitary field seems very important for efforts to maintain the capability of the Indonesian state in the defense and security sector [3]. There is a growing desire to widen the scope of military activity in order to minimize the possibility of civilian politicians' further interference in internal military affairs. In addition, the military had almost completely lost confidence in political parties, so that a new force was needed to overcome the power vacuum.

In this new political order, Abdul Haris Nasution has succeeded in placing Army representatives in the government, legislative bodies, and in almost all state apparatus. The military has a say in administering the law, and is becoming increasingly involved in managing the national economy. As such, it appears that the military is in a good position to defend its interests and policies. Increasingly, the main military, the Army, is increasingly consolidating its position in the political arena of the state and nation [21]. From its political objectives, the Army acts as a builder of unity and integrity, guardian of the 1945 
Constitution and Pancasila, national shield, dynamist and stabilizer of the nation.

\section{Military Political Participation in the Indonesia- Malaysia Confrontation}

One of the very strategic and attention-grabbing issues that Indonesia has faced in the past is the decision of President Soekarno to take action to confront Malaysia [22]. This problem started in 1963 and was caused by various factors. First, the confrontation occurred because Indonesia was suspicious of the British intention to change the Tanah Melayu alliance into a Malaysian state which included Malaya, Singapore, Sarawak and North Kalimantan. Because at that time there was an effort between Indonesia, Malaya, and the Philippines to form the Maphilindo alliance which stands for Malaya, Philippines and Indonesia. Maphilindo is intended as an alliance of the Malay family in Southeast Asia and is a joint concept between Soekarno, Macapagal from the Philippines and Tungku Abdul Rahman from the Malay Land Association [23]. At that time the military fully supported the creation of Maphilindo as an effort to unite the Malay family. Second, namely the PKI's insistence which of course received support from Moscow and Beijing so that Indonesia would oppose the Malaysia concept [24]. Not only against by means of diplomacy but also with actions that use physical force. The PKI has an interest in confrontation, because it is hoped that it can confuse the atmosphere within the Indonesian state [25].

For the Indonesian side, the military in general and the army in particular gave consideration to the immediate end of the confrontation with peace. There are several reasons for the military to resolve the confrontation immediately. First is the consideration of military strategy [26]. Based on these considerations the Army has carefully calculated that with the confrontation with Malaysia, Indonesia is far from being able to achieve the goal of breaking Malaysian military power. Indonesia will not only face Malaysia, but will also face Britain and the forces behind it, for example Australia, New Zealand and the United States, which must be admitted that they have a fairly strong military force both in terms of personnel and weaponry. The second consideration is a political factor. If there was an open war with Malaysia and its supporting countries, the military would have to devote many of its fighting forces to the luta island of Java. The vacuum of Java could pose a danger to the capital Jakarta, given the national political situation which tended to be dominated by the PKI [27]. It was not impossible that the PKI could exploit the void of combat troops in Java in launching a power struggle. The third consideration which is implicit, because it has never been clearly revealed, is economic considerations [28]. War everywhere is also very costly. It is difficult for Indonesia, which is currently in a very weak economic condition, to carry out the war successfully.

Basically, the foremost motivation that existed among the military groups who initiated the reconciliation effort was to help the Indonesian government end the confrontation as quickly as possible. Efforts must be made so that both parties are willing to appear at the negotiating table in a respectful manner, namely without losing face and without accusing each other of who is guilty. On the Indonesian side, unlike the Malaysian side which was initiated by civilian officials, the pioneers of the reconciliation effort or peace feelers even came from the military, namely the Army [29]. Among them, Ahmad Yani, Soeharto, Ali Moertopo, L.B. Moerdani, A. Rahman Ramli, Soegeng Drajat, Yogie Soegomo Memed, and Soepardjo Roestam. Meanwhile, on the Malaysian side there are Tan Sri Muhammad Ghazali Bin Shafis, Tun Abdul Razak and Muhammad Sulon [30].

So, Indonesia's problem in the confrontation with Malaysia did not lie in the attitude of the confrontation itself, but in the attitude of not taking into account the objective strength of Indonesia to be able to carry out the confrontation with good results. Politically, the attitude of confrontation was not wrong, because indeed Britain, with the help of the United States and friends, showed an opposing attitude towards the unity of the Malays and wished to resume its colonial practice in Southeast Asia. However, if the objective power possessed by Indonesia is inadequate in carrying out confrontation, what is wrong when some of the Indonesian nation's children resort to other methods which are considered more guaranteeing their success in the political arena.

Based on the maturity of such thinking and strategy, Army officers considered that the politics of confrontation as long as it was limited to political and economic confrontation were tolerable and accommodated. But if the confrontation had led to open military physical warfare, the impact was seen to be too great, not only for the military, but also for the entire Indonesian people.

\section{CONCLUSION}

The occurrence of regional upheaval that wanted to separate itself from the Unitary State of the Republic of Indonesia as well as the foreign policy problems faced by the Indonesian State during the Soekarno era had seriously caught the attention of the military. The civilian government originating from political parties is deemed incapable of overcoming this. In fact, they conflict with each other in the interests of their respective parties. Departing from this, the military primarily from the Army, on the initiative of Abdul Haris Nasution, brought the military to participate actively in overcoming the national issue. The military must be involved in national policies in the fields of domestic politics, economy and finance as well as international relations for the sake of the integrity of the Unitary Republic of Indonesia.

\section{ACKNOWLEDGMENT}

Thanks to the Dean of the Fakultas Ilmu Sosial, Universitas Negeri Makassar who have provided financial support for this research.

\section{REFERENCES}

[1] S. Scagliola, "The Silences and Myths of a dirty War: Coming to Terms with the Dutch Indonesian Decolonisation War (1945-1949)," Eur. Rev. Hist. Rev. Eur. d'histoire, vol. 14, no. 2, pp. 235-262, 2007.

[2] S. Said, "The Genesis of Power: Civil-Military Relations in Indonesia During the Revolution for Independence, 1945-1949." The Ohio State University, Ohio, 1986.

[3] M. Mietzner, Military Politics, Islam, and the State in Indonesia: From Turbulent Transition to Democratic Consolidation. Institute of Southeast Asian Studies, 2009. 
[4] H. Crouch, The Army and Politics in Indonesia. Cornell University Press, 2019.

[5] M. Haripin, A. Priamarizki, and K. I. Marzuki, The Army and Ideology in Indonesia: From Dwifungsi to Bela Negara. Routledge, 2020.

[6] Y. A. Muhaimin, "Perkembangan Militer dalam Politik di Indonesia 1945-1966: Kata Pengantar 2002.” Gadjah Mada University Press, Yogyakarta, 2002.

[7] J. Braithwaite, V. Braithwaite, M. Cookson, and L. Dunn, Anomie and Violence: Non-Truth and Reconciliation in Indonesian Peacebuilding. ANU Press, 2010.

[8] H. Sulistiyo, "Ethnoreligious Issues and the Indonesian Armed Forces," Polit. Multicult. Plur. Citizsh. Malaysia, Singapore, Indones., p. 291, 2001.

[9] I. G. Sardjana, "Civil Military Relations. The Role of ABRI in Indonesian Socio-Political Life.," NAVAL POSTGRADUATE SCHOOL MONTEREY CA, 1995.

[10] R. Eatwell and M. Goodwin, National Populism: The Revolt Against Liberal Democracy. Penguin UK, 2018.

[11] B. Turner, AH Nasution and Indonesia's Elites:" people's Resistance" in the War of Independence and Postwar Politics. Lexington Books, 2017.

[12] B. R. Anderson, "Old state, new society: Indonesia's new order in comparative historical perspective," J. Asian Stud., vol. 42, no. 3, pp. 477-496, 1983.

[13] L. C. Sebastian, Realpolitik Ideology: Indonesia's Use of Military Force. Institute of Southeast Asian Studies, 2006.

[14] A. Susilo, "Sejarah Perjuangan Jenderal Soedirman dalam Mempertahankan Indonesia (1945-1950)," Hist. J. Progr. Stud. Pendidik. Sej., vol. 6, no. 1, pp. 57-68, 2018.

[15] S. Minurdin, "Kiprah Komando Pasukan Sandhi Yudha dalam operasi militer di Indonesia tahun 1971-1985," FACTUM J. Sej. dan Pendidik. Sej., vol. 7, no. 2, pp. 241-254, 2018 .

[16] M. C. Desch, Civilian Control of the Military: The Changing Security Environment. JHU Press, 2008.

[17] R. Mortimer, Indonesian Communism Under Sukarno: Ideology and Politics, 1959-1965. Equinox Publishing, 2006.

[18] A. Rabasa and J. Haseman, The Military and Democracy in Indonesia: Challenges, Politics, and Power. Rand Corporation, 2002.

[19] U. Sundhaussen, "Politik Militer Indonesia 1945-1967, Menuju Dwi Fungsi ABRI.," Hasan Basri, Jakarta: LP3ES, 1986.

[20] B. I. Reza, "The Total People's Defense and Security System: Issues Related to State-Sponsored Militia in Indonesia," Indon. L. Rev., vol. 7, p. $155,2017$.

[21] L. McCulloch, "Trifungsi: The Role of the Indonesian Military in Business," in The military as an economic actor, Springer, 2003, pp. 94-123.

[22] M. C. Ricklefs, Sejarah Modern Indonesia 1200-2004. Jakarta: PT Serambi Ilmu Semesta, 2005.

[23] M. Jones, Conflict and Confrontation in South East Asia, 1961-1965: Britain, the United States, Indonesia and the Creation of Malaysia. Cambridge University Press, 2001.

[24] D. Hindley, "Indonesia's confrontation with Malaysia: A search for motives," Asian Surv., vol. 4, no. 6, pp. 904-913, 1964.

[25] L. Chua, "Konfrontasi: Rethinking explanations for the IndonesiaMalaysia confrontation, 1963-1966." Massachusetts Institute of Technology, 2001

[26] W. B. L. S. Wardani, "Indonesia-Malaysia Relations in the Post Confrontation Era: The Role of the Serumpun Concept," dalam J. Masy. Kebud. dan Polit., vol. 12, no. 4, 2010

[27] W. H. Frederick and R. L. Worden, Indonesia: A Country Study, vol. 550, no. 39. Government Printing Office, 1993.

[28] A. Kahin and G. M. Kahin, Subversion as Foreign Policy: the Secret Eisenhower and Dulles Debacle in Indonesia. University of Washington Press, 1997.

[29] J. B. Tamney, The Struggle Over Singapore's Soul: Western Modernization and Asian Culture, no. 70. Walter de Gruyter, 1996.

[30] H. Mukmin, TNI Dalam Politik Luar Negeri: Studi Kasus Penyelesaian Konfrontasi Indonesia-Malaysia. Jakarta: Pustaka Sinar Harapan, 1991. 